\title{
The artistic truth: coherence, cohesion and credibility in Jane Austen's novels
}

\author{
Miguel Ángel Jordán
}

\author{
Department of English Studies of Universidad de Valencia (Spain) Vice President of Jane Austen Society of Spain. \\ E-mail Id: miguel.jordan@uv.es
}

\begin{abstract}
Any literary work is composed of different elements both in its formal part and in the subject matter. The author's mission is to achieve that these elements fit harmoniously, so that the work is perceived as a whole and not as a merger of parts. To achieve this unity in the work, it is essential that there is internal cohesion between its different elements. And coherence in the argument and its various parts will also be necessary for the reader to perceive it as something logical and, in this way, to create the sensation of reality that a work of fiction must provide. In this article, we will analyze some of the strategies used by Jane Austen to give unity to her work and confer on her stories the degree of credibility needed.
\end{abstract}

Keywords-Jane Austen, coherence, literary analysis, structure, Nineteenth Century literature.

\section{INTRODUCTION}

During the process of literary creation, the author must not only take into account the story he wants to narrate, but also the environment in which that story is placed, the characters that participate in it, the circumstances and consequences of the acts narrated, etc. All these factors will influence in a determinant way the perception of the reader and will contribute to create in him a certain sense of reality, even though both the protagonists of the story and everything that happens in it are the result of a writer's invention.

The good reader is aware that the quest for real life, real people, and so forth is a meaningless process when speaking of books. In a book, the reality of a person, or object, or a circumstance depends exclusively on the world of that particular book. An original author always invents an original world, and if a character or an action fits into the pattern of the world, then we experience the pleasurable shock of artistic truth, no matter how unlikely the person or thing may seem if transferred into what book reviewers, poor hacks, call "real life." There is no such thing as real life for an author of genius: he must create it himself and then create the consequences. (Nabokov 10)

In this article, we will study the strategies that Austen uses to achieve the artistic truth; how she gets her audience to perceive the narration as something possible and true.

Both cohesion and coherence are closely related to unity. Although the novel is divided into books, chapters or other sections, the goal of the good storyteller is that the work will be perceived as a whole. To achieve harmony, all parties must fulfill their mission and not stand out above expectations. Moreover, the ideal is that, throughout the narrative, we find elements that reinforce unity.

In addition to the unit, both structural and of content, credibility is also a very important feature. That is to say, the events that make up the storyline must happen logically and have to be seen as possible. We must find the justification of all actions and thoughts within the text. This does not imply that everything should be explained, but that characters and the context should be presented in such a way that what happens next is a logical consequence, or at least not so disconcerting that it causes strangeness and rejection in the reader.

\section{ANALYSIS OF JANE AUSTEN'S} LITERARY STRATEGIES

\subsection{Preparing the problems and conflicts.}

In Austen's novels, as in many other works, we find an introductory phase in which, in addition to presenting the characters and their environment, the bases for the various conflicts that will develop the plot are also established..

A Jane Austen novel proceeds in two phases. In the first, the heroine is shown in her original circumnstances: her family, natural or substituted; her circle of acquaintances: her economics advantages or disadvantages. Above all, we are shown her basic temperament, and the qualities of her nature which make for her happiness in this environment. (...). The second phase begins with the appearance of the character or characters whom 
I have termed in the previous section the "primary antagonist" (...). This phase also brings to a crisis whatever in the heroine's nature constitute an obstacle to her favourable destiny. The effect of both elements is usually, first, to make the heroine aware of her confinement, or of the painfulness of it, as never before, and secondly to make the confinement seem inevitable and permanent just when she is developing urgent desires for release. (Gillie: 117)

One of Austen's resources for providing cohesion to her works is to introduce briefly - sometimes with just one quote - characters or themes that will appear later. And it is also frequent that this author offers some information that the reader will not fully understand until he reaches a more advanced point in the story.

In the following paragraphs, we will delve a little deeper into these strategies. A clear example of how possible conflicts can be identified is found in Mansfield Park. In the following text, we will see how we are offered the point of view of Maria Bertram and Henry Crawford, taking away from something that will end up being decisive.

Maria's notions on the subject were more confused and indistinct. She did not want to see or understand. "There could be no harm in her liking an agreeable man- everybody knew her situation-Mr. Crawford must take care of himself." Mr. Crawford did not mean to be in any danger! the Miss Bertrams were worth pleasing, and were ready to be pleased; and he began with no object but of making them like him. He did not want them to die of love; but with sense and temper which ought to have made him judge and feel better, he allowed himself great latitude on such points. (MP: 39)

Afters having said that, all the narrator has to do is raising the intensity of the relationship on both sides until it reaches the critical point.

In a different style is the example we will offer now, drawn from Persuasion. In this case, the narrator shows us the feelings of the protagonist without adding any comments. However, when we perceive her embarrassment, we understand that it is an important issue that can become the center of the story.

Mr. Shepherd was completely empowered to act; and no sooner had such an end been reached, than Anne, who had been a most attentive listener to the whole, left the room, to seek the comfort of cool air for her flushed cheeks; and as she walked along a favourite grove, said, with a gentle sigh, "A few months more, and he, perhaps, may be walking here." (P: 60)

Something similar happens in the following excerpt, but this time the narrator is responsible for showing the emotions in a more partial way, so that we not only perceive the feelings of a character, but also her intentions.

Miss Bingley saw, or suspected enough to be jealous; and her great anxiety for the recovery of her dear friend Jane received some assistance from her desire of getting rid of Elizabeth. (P\&P: 45)

Miss Bingley's jealousy of Elizabeth will be one of the conflicts present during almost all the novel, although it will change of plane depending on the circumstances.

Another option is for a character to declare his or her intentions and establish "officially" one of the conflicts in the plot. This is the case we can find in Emma:

"Only one more, papa; only for Mr. Elton. Poor Mr. Elton! You like Mr. Elton, papa,--I must look about for a wife for him. There is nobody in Highbury who deserves him--and he has been here a whole year, and has fitted up his house so comfortably, that it would be a shame to have him single any longer--and I thought when he was joining their hands to-day, he looked so very much as if he would like to have the same kind office done for him! I think very well of Mr. Elton, and this is the only way I have of doing him a service." (E: 9)

Not only are conflicts or critical points of the story prepared in advance. Sometimes, it is announced an event (a dance, a meeting, a field trip, etc.) that will not take place until later. The preparation of this event will not only provide cohesion to the work, but also, at times, it will allow us to know more profoundly some of the characters that will participate in this activity.

First, Jane Austen prepares the event carefully. References to the ball are evensly spaced during the first seventy pages and it becomes steadily more likely. Second, Jane Austen uses the preparations to bring out the pleasentness of $\mathrm{Mr}$. Bingley (...). Structurally, this helps us too understand that the novelist has created a relationship between character and events: the ball -an event in the story- is an expression of the benevolence we find in Blingley $-\mathrm{a}$ character. (Marsh 69) 


\subsection{Providing information which justifies future} events.

In her eagerness to take care of the detail and show us "real" stories, Austen leaves nothing to chance. In her novels we rarely find a completely unexpected situation, either for good or for bad. The changes of attitude, disappointments or any event can be explained by going back a few pages to observe the signs that bordered the road. It can be a conversation between some characters, or a comment from the narrator, either about something that happened at the time of the story or outside it. "Sometimes an omniscient narrator informs his / her readers about facts which have taken place on a different temporal plane" (Morini 29) This attitude is among the advice that Austen offered to her niece Anne Lefroy in one of her letters.

And had you not better give some hint of St. Julian's early history in the beginning of the story? (Letters: 297)

Sometimes, the narrator provides information that may seem unnecessary at first, but will be very relevant soon after. In Sense and Sensibility, when planning a jouney to some nearby location, we are told:

A party was formed this evening for going on the following day to see a very fine place about twelve miles from Barton, belonging to a brother-in-law of Colonel Brandon, without whose interest it could not be seen, as the proprietor, who was then abroad, had left strict orders on that head. (S\&S: 53)

The presence of Colonel Brandom is essential so that the group can spend the day in that property of his brother-in-law. Is this important enough for the narrator to highlight it? Yes, since, when the colonel receives a letter that forces him to be absent, not only will he miss the party, but he will also be forcing others to change plans, causing the consequent complaints, criticisms and suspicions.

In the same novel we find another example of how the narrator is preparing the ground for what will happen next. Willoughby is shown at the beginning as a handsome and nice young man. Nothing in his person foreshadows his change of attitude towards Marianne. But if we review the text, we will find the following information:

His estate had been rated by Sir John at about six or seven hundred a year; but he lived at an expense to which that income could hardly be equal, and he had himself often complained of his poverty. (S\&S: 61)

This economic situation and his habit of living above his income justify that, later, he will decide to marry a young woman of good position instead of Marianne.

Very similar is the case of John Thorpe, who with his usual abrupt manners, keeps the following conversation with Catherine.

"Old Allen is as rich as a Jew - is not he?" Catherine did not understand him - and he repeated his question, adding in explanation, "Old Allen, the man you are with."

"Oh! Mr. Allen, you mean. Yes, I believe, he is very rich."

"And no children at all?"

"No - not any."

"A famous thing for his next heirs. He is your godfather, is not he?"

"My godfather! No."

"But you are always very much with them."

"Yes, very much."

"Aye, that is what I meant. " (NA: 38)

The naive girl is not able to follow the thread of the young man's thoughts, but the reader does. And, in case there is any doubt, a little later the narrator will clarify that Mr. Thorpe was convinced of the good economic situation of Catherine and not only pretended to benefit from it, but strutted in front of General Tilney, causing the great confusion that it is told in the novel.

It can also happen that some characters maintain a conversation in which one of them offers a point of view that the other rejects, but then turns out to be true. We have already seen Anne's case when she warned her sister of the inherent danger in Mrs. Clay. We will now see Charlotte's opinion on Jane's attitude.

"If a woman conceals her affection with the same skill from the object of it, she may lose the opportunity of fixing him; and it will then be but poor consolation to believe the world equally in the dark (...) Bingley likes your sister undoubtedly; but he may never do more than like her, if she does not help him on." (P\&P: 17)

Lizzy protests strongly at this argument, but time will show the truth of Charlotte's words.

Characters' behaviour must be consistent with what we know of them, therefore, the author will have to show us different features of them to justify their attitude. Otherwise, the reader could be disconcerted and thus the story would lose credibility. For example, in the final part of Pride and Prejudice, we find a dialectical confrontation between Elizabeth Bennet and Lady Catherine de Bourgh. The firmness of Elizabeth in front of this lady of high social position and energetic character could surprise the readers and seem incoherent if the narrator had not offered some information previously. 
It looks as though Jane Austen was aware herself that this criticism might be made and took steps to meet it. In anticipation of this scene, Lizzy is made to answer back to Lady Catherine on her visit to Rosings, many chapters before, and Lady Catherine remarks on how forward she is for a young woman in expressing her own opinions. (Jenkyns: 44)

The author's caution, by putting certain words in the mouth of a character, justifies the protagonist's way of acting many chapters later and maintains the sensation of reality.

\subsection{Giving clues to the reader.}

The narrator, from his omniscient perspective, manages the information that he will reveal at each moment. Austen's readers always go several steps behind the narrator, but they sometimes overtake the characters; Or, better said, they have that possibility if they are attentive, since it is not uncommon that some clues have been left throughout the story, which allow us to guess what is going to happen.

In both Emma and Northanger Abbey the reader's advantage over the protagonist is striking. In the first case it is due to the self-sufficiency of the young woman, who thinks that she knows more than those around her and that her judgments are always right. The reader, especially in a second reading, finds a huge amount of clues that are marking the course of events.

The tight construction of Emma and the alertness required to solve the mystery and understand the art of Austen in educating her readers is illustrated by the story of Jane and Frank. The clues, like the purloined letter, are hiding in plain sight-Frank's repeated postponements of a visit to Highbury until Jane's arrival, the evasiveness of both Frank and Jane when questioned about their acquaintance at Weymouth, the discussion of the post office, the timing of the arrival of the piano, Miss Bates's chatter at the Crown-but these clues seem insignificant when encountered and are easy to overlook. The imperceptive reader shares Emma's astonishment at the denouement of the episode, but the reader who has heeded the lesson in reading provided by the novel enjoys the pleasure of solving the mystery and negotiating the hermeneutic difficulty-the most significant pleasures to be derived from reading Emma. (Duckworth: 103)

In the second work, the public's advantage is due to Catherine's naivety, which leads her to believe the words without paying attention to attitudes. In her candour, the young woman does not detect the falseness of her "faithful friend" Isabella, the interest of John Thorpe, or the surprising deference shown by General Tilney, taking into account his social position. In this case, the road is not marked only by clues, but rather we find large illuminated signs visible to everyone, except for Miss Morland.

Let's see some examples of the clues that are offered to us in these and other works of Austen and the destiny to which they lead.

When Edward Ferrars visits the Dashwoods in their new home, we are told that, at the beginning, his attitude is somewhat strange, but after some casual talk he relaxes a little and starts becoming himself again. This should not be striking, since they had not seen each other for some time, and we also know that he is a shy young man. However, in an "innocent" dialogue, Edward reacts in a way that surprises both the characters and the reader.

"If I could persuade myself that my manners were perfectly easy and graceful, I should not be shy."

"But you would still be reserved," said Marianne, "and that is worse."

Edward started--"Reserved! Am I reserved, Marianne?"

"Yes, very."

"I do not understand you," replied he, colouring. "Reserved!--how, in what manner? What am I to tell you? What can you suppose?"

Elinor looked surprised at his emotion (S\&S: 81)

From this moment, any attentive reader will suspect the sincerity of Edward and will intuit the existence of a compromising secret.

In the following case, it is not an uncontrolled reaction, but a statement with double meaning that betrays the character and allows the public to guess the future.

"I would not speak disrespectfully of a brother of yours, Isabella, I am sure; but you know very well that if I could think of one man more than another - he is not the person." Isabella was silent. "My dear friend, you must not be angry with me. I cannot suppose your brother cares so very much about me. And, you know, we shall still be sisters." "Yes, yes" (with a blush), "there are more ways than one of our being sisters." (NA: 89)

Catherine is not interested in John Thorpe, but in Henry Tilney. Isabella is engaged to Catherine's brother, but feels attracted by Frederick Tilney. Certainly, there is more than one way to end up being sisters. Catherine does not understand, but almost no reader will be surprised when the breakup of Miss Thorpe and James Morland takes place. 
We have already talked about Emma, and the large number of clues we found. Some are obvious, like those that make us see that Mr. Elton is not interested in Harriet but in his friend and protector; but others may not be detected in the first reading. This could be the case of Mr. Knightley's jealousy of Frank Churchill, which leads him to judge the young man harshly on each occasion. And although Frank Chuchill usually deserves the reproaches of Mr. Knightley, many readers could be dissapointed by the fact that this gentleman, always so correct and restrained, does not refrain from commenting on the young person every time he is named.

"I will say no more about him," cried Emma, "you turn every thing to evil. We are both prejudiced; you against, I for him; and we have no chance of agreeing till he is really here."

"Prejudiced! I am not prejudiced." (...) "He is a person I never think of from one month's end to another," said Mr. Knightley, with a degree of vexation, which made Emma immediately talk of something else, though she could not comprehend why he should be angry. (E: 133)

He says he does not think about him, but his attitude corrects his words. Later we will know that his prejudices were based on the fear that Emma would fall in love with Frank. Although some readers may not need to reach the end of the story to intuit that this is the case.

The attitude of a character, different from the expected by what had been seen until then, is a resource that Austen often uses to announce changes. In the previous examples we have seen that these clues announced a secret, or revealed the true intentions, or the hidden feelings of a character. We will see now how they can also show the authentic personality of one of the protagonists, even if she tries to silence this fact, which will then prove relevant.

The sudden acquisition of ten thousand pounds was the most remarkable charm of the young lady to whom he was now rendering himself agreeable; but Elizabeth, less clear-sighted perhaps in this case than in Charlotte's, did not quarrel with him for his wish of independence. Nothing, on the contrary, could be more natural; and while able to suppose that it cost him a few struggles to relinquish her, she was ready to allow it a wise and desirable measure for both, and could very sincerely wish him happy. (P\&P: 132)

Mr. Wickham, who seemed in love with Lizzy, suddenly changes his attentions to a young woman whom he did not know anything about, and whose greatest merit is having received a fortune. However, Elizabeth, who is usually perceptive, does not see the peculiarity of the case and plays down her importance. Until Mr. Darcy's letter opens his eyes to reality.

\subsection{Providing evidence.}

To certify the veracity of an argument, the two most frequent resources are witnesses and evidence. In Austen's novels we find both, but we will only delve in the second element, since they are the most irrefutable of the two, although we will also refer indirectly to the first.

With these proofs, the narrator -directly or through a character- not only convinces the corresponding interlocutor, but also the reader. This is what happens, for example, when Lucy Steele claims to be engaged to Edward Ferrars. Although it is true that we suspected something was happening, both Elinor and those who read the story find it difficult to believe that this young woman, with hardly anything recommending her, would have reached such a point of intimacy with Edward. To settle this disbelief, Lucy shows two irrefutable evidence.

"I heard from him just before I left Exeter;" taking a letter from her pocket and carelessly showing the direction to Elinor. "You know his hand, I dare say, a charming one it is; but that is not written so well as usual.--He was tired, I dare say, for he had just filled the sheet to me as full as possible."

Elinor saw that it was his hand, and she could doubt no longer. (...) I gave him a lock of my hair set in a ring when he was at Longstaple last, and that was some comfort to him, he said, but not equal to a picture. Perhaps you might notice the ring when you saw him?" (S\&S: 116)

In Pride and Prejudice we find two types of tests. The first would be linked to the indirect testimony of a witness. That is, some words that were not understood at the time are now used to certify the truth of a recent statement.

But, alas! the story which followed, of his designs on Miss Darcy, received some confirmation from what had passed between Colonel Fitzwilliam and herself only the morning before. (P\&P: 181)

Elizabeth is reluctant to believe all that $\mathrm{Mr}$. Darcy tells about Wickham in his letter, but her honesty prevents her from resisting the evidence. The first has already commented. The following comes in the form of reflection on the past with a new light. Some facts, that seemed irrelevant, are enlightening after receiving certain information.

She was now struck with the impropriety of such communications to a stranger, and wondered it had escaped her before. She saw the indelicacy of putting himself forward as he had done, and the 
inconsistency of his professions with his conduct. She remembered that he had boasted of having no fear of seeing Mr. Darcy--that Mr. Darcy might leave the country, but that he should stand his ground; yet he had avoided the Netherfield ball the very next week. She remembered also that, till the Netherfield family had quitted the country, he had told his story to no one but herself; but that after their removal it had been everywhere discussed; that he had then no reserves, no scruples in sinking Mr. Darcy's character, though he had assured her that respect for the father would always prevent his exposing the son. (P\&P: 181)

Both Lizzy and the reader understand the truth of Mr. Darcy's words in assessing Wickham's attitude.

This strategy and those that we have analyzed so far not only provide unity to the story linking different moments, but also bring a great sense of reality. The events follow one another logically, one can "predict the future" as a consequence of the characters' personality and behaviour, and we find elements that certify the truth of what is presented here.

\subsection{Timelessness}

Despite the time that has elapsed since her writing, it is interesting to see that Jane Austen's works have not been outdated, nor are they strange or distant to current readers.

Although the sociocultural context is different, and some references highlight the passage of time, the events that are narrated and, above all, the personal feelings and attitudes are still valid. This is because in her novels Austen delves into the person. The exterior -which is what changes over time- is just a support to reflect the inner world of each protagonist.

This timelessness of situations makes it easier for readers to recognize them and perceive what is narrated as something close and real. They can go from something intimate, like the first infatuation:

Jane was not happy. She still cherished a very tender affection for Bingley. Having never even fancied herself in love before, her regard had all the warmth of first attachment, and, from her age and disposition, greater steadiness than most first attachments often boast; and so fervently did she value his remembrance, and prefer him to every other man, that all her good sense. (P\&P: 199)

To something much more external, like the taste of women to get ready and the insensibility of men to value these details.

This would have been an error in judgment, great though not uncommon, from which one of the other sex rather than her own, a brother rather than a great aunt, might have warned her, for man only can be aware of the insensibility of man towards a new gown. It would be mortifying to the feelings of many ladies, could they be made to understand how little the heart of man is affected by what is costly or new in their attire; how little it is biased by the texture of their muslin, and how unsusceptible of peculiar tenderness towards the spotted, the sprigged, the mull, or the jackonet. Woman is fine for her own satisfaction alone. No man will admire her the more, no woman will like her the better for it. (NA: 45)

Or the passion of men for vehicles and their desire to compare their own with those of others.

The word curricle made Charles Musgrove jump up that he might compare it with his own. (P: 153)

Human limitations, defects and bad habits also resist the passage of time. Be it in the form of morbid curiosity:

By this time the report of the accident had spread among the workmen and boatmen about the Cobb, and many were collected near them, to be useful if wanted, at any rate, to enjoy the sight of a dead young lady, nay, two dead young ladies, for it proved twice as fine as the first report. (P: 159)

Or showing the ingenuity of a father who not only is not able to educate and control the actions of his daughters, but is so naive as to think that they are still innocent girls, and that they have had nothing to do with the incidents in which they have been involved.

"He, her father, a well-meaning, but not a quicksighted man, could really, I believe, give no information; for he had been generally confined to the house, while the girls were ranging over the town and making what acquaintance they chose; and he tried to convince me, as thoroughly as he was convinced himself, of his daughter's being entirely unconcerned in the business." (S\&S: 178)

\subsection{Characters from "different worlds" converge.}

Emma is the only Jane Austen novel in which the plot unfolds completely in the same place. Within this scenario, we find different environments: Hartfield, Randalls, Donwell Abbey, the town of Highbury with its various homes and establishments, etc. But it is a limited location.

In the other works, the protagonists change the scenario one or more times. Each of these environments usually brings together a group of different characters. It is the protagonist who creates the link between these different settings. But this unity can be reinforced by other characters. 
We find an example of this in Sense and Sensibility when Edward Ferrars is benefited by the generosity and understanding of Colonel Brandom, and meets him in person. Until then, their stories had gone through very different paths. Colonel Brandom belongs to the circle of Mrs. Jennings and her family, while Edward moved around the Ferrars.

Catherine travels first to Bath with the Allen, and then to Northanger Abbey with the Tilneys. Her home had been the point of departure and return, and everything that happened during her travels seemed outside of family boundaries. Until Henry Tilney goes to visit her to explain what happened and present his excuses, and marriage proposal.

Something similar is found in Mansfield Park when Henry Crawford travels to Portsmouth, following the footsteps of Fanny, and meets the Price family. Or, even more surprising, the unexpected visit of Lady Catherine de Bourgh to Longbourn, home of the Bennets.

Threads that come together to form a tapestry full of colours and well-defined figures.

\subsection{Closing the story in a consistent way}

The end of a story is decisive to be able to assess the three aspects that we are analyzing in this section: coherence, cohesion and credibility. A good conclusion will ensure that readers perceive that story as something complete and true. Otherwise, the public will feel dissatisfied, there will be questions in the air, confusion will occur and the sense of reality will be broken.

In all Austen's novels we find a happy ending for the protagonists. Although the stories that are told are different, there are two common elements in the closure of all of them:

-The protagonist marries the man she loves.

-The protagonist improves her social and economic position.

As it can be seen in all these works, the path to happiness is never easy, and there is always a time when it seems that the goal will not be reached. But Austen gives a happy ending to her readers, who will enjoy it even more because it is the result of a long process in which the protagonists have behaved in a virtuous manner.

The end is a consequence of all the above. There is no shocking surprise that changes the circumstances in a sudden and inexplicable way. For this reason, "the good ones" end well and "the bad ones" do not always end badly, at least from the point of view of material wellbeing, since in real life there are times when the villains succeed.

For example, in the case of Willoughby, who is, along with Wickham, one of the main villains of Austen's novels, we are told that he regretted his attitude when he realized that he could have achieved the fortune he longed for and, besides, could also have married the woman he preferred. But it is a very superficial repentance. He is not hurt by the suffering he caused, nor by his selfish and cruel way of acting, but by having been unskilled in playing his cards. His is the lament of someone who has lost a bet he could have won. And, for this reason, there is no change in his attitude and he is not condemned to a life of torment. He is a capricious and superficial young man, who will lead a life according to his personality, and who will not be denied some joys.

Willoughby could not hear of her marriage without a pang; and his punishment was soon afterwards complete in the voluntary forgiveness of Mrs. Smith, who, by stating his marriage with a woman of character, as the source of her clemency, gave him reason for believing that had he behaved with honour towards Marianne, he might at once have been happy and rich. That his repentance of misconduct, which thus brought its own punishment, was sincere, need not be doubted;--nor that he long thought of Colonel Brandon with envy, and of Marianne with regret. But that he was for ever inconsolable, that he fled from society, or contracted an habitual gloom of temper, or died of a broken heart, must not be depended on--for he did neither. He lived to exert, and frequently to enjoy himself. His wife was not always out of humour, nor his home always uncomfortable; and in his breed of horses and dogs, and in sporting of every kind, he found no inconsiderable degree of domestic felicity. (S\&S: 330)

In the case of the other villain, the result is less favourable, but it is a consequence of his way of acting. Willoughby resigned Marianne to marry a young woman with much more money, so he could enjoy her fortune. Wickham also married a girl he did not love, but in this case there was no economic counterweight to balance the scales. So his final is as expected for him as for Lydia.

They were always moving from place to place in quest of a cheap situation, and always spending more than they ought. His affection for her soon sunk into indifference; her's lasted a little longer; and in spite of her youth and her manners, she retained all the claims to reputation which her marriage had given her. (P\&P: 339)

That is, people who move for economic interest can achieve their objectives if they are skilled. The lack of morality can have positive consequences from the point of view of economic welfare. But what happens to those 
who act moved by other desires? Well, they also receive the fruit of what they have been sowing.

In the case of Sir Walter and Elizabeth Elliot, their selfishness, servile attitude towards titles and their arrogance make them victims and slaves of those who overcome them in cunning and position.

It cannot be doubted that Sir Walter and Elizabeth were shocked and mortified by the loss of their companion, and the discovery of their deception in her. They had their great cousins, to be sure, to resort to for comfort; but they must long feel that to flatter and follow others, without being flattered and followed in turn, is but a state of half enjoyment. (P: 318)

Not very different is the case of Maria Bertram and Mrs. Norris, who suffer the consequences of their actions and attitudes. Maria has been carried away by caprice, vanity and passion, but she has lacked understanding to comprehend the situation and value the impact of her decisions. And Mrs. Norris has always acted in an interested way, seeking only her own satisfaction. The affection she felt for hier nieces was loaded with selfishness, as she sought to stand out through them and gain their esteem by consenting them, instead of striving to educate them. And her attitude towards others, especially towards Fanny, was always unjust and tyrannical. So the consequences for both are logical.

It ended in Mrs. Norris's resolving to quit Mansfield and devote herself to her unfortunate Maria, and in an establishment being formed for them in another country, remote and private, where, shut up together with little society, on one side no affection, on the other no judgment, it may be reasonably supposed that their tempers became their mutual punishment. (MP: 417)

\section{CONCLUSION}

As it has been seen, through the examples offered, Austen has an overview of her novels that allows her to manage the information so that both the attitude of the characters and other circumstances contribute to the unity of the work.

The narrator of these novels acts like an orchestra conductor that marks the rhythm of the plot, distributes the protagonism between the different characters and manages to make everything flow with harmony. This harmony, which provokes in the reader the sensation of reality, is the result of many factors that usually go unnoticed. In the same way that a wellmounted and greased gear barely makes any noise, a wellconstructed narrative does not attract attention. It is the discordant elements that stand out above the rest, reminding the audience that they are reading a work of fiction and taking them back to reality. For that reason, the aim of every author is that the global harmony will prevent readers to pay attention to particular details so that they can admire the beauty of the whole.

\section{REFERENCES}

[1] Austen, Jane. Emma. Richard Bentley, 1841.

[2] Austen, Jane. Jane Austen's Letters. Editado por Le Faye, Deirdre. OUP Oxford, 2011.

[3] Austen, Jane. Mansfield Park. Richard Bentley, 1833.

[4] Austen, Jane. Northanger Abbey. Wild Jot Press, 2009.

[5] Austen, Jane. Pride and Prejudice. Richard Bentley, 1853.

[6] Austen, Jane. Sense and Sensibility. Richard Bentley, 1833.

[7] Duckworth, William C. Jr. «Misreading Jane Austen: Henry James, Women Writers, and the Friendly Narrator». Persuasions: The Jane Austen Journal, 1999.

[8] James, Henry. The Portable Henry James. Penguin, 2003.

[9] King, Virginia. "Novel readings: The history of a writing community by a partial, prejudiced, \& ignorant Historian." Arts and Humanities in Higher Education 12.1 (2013): 88-104.

[10] Lambdin, Laura C., y Lambdin, Robert T., eds. A Companion to Jane Austen Studies. Greenwood Publishing Group, 2000.

[11] Morini, Massimiliano. Jane Austen's Narrative Techniques: A Stylistic and Pragmatic Analysis. Ashgate Publishing, Ltd., 2013.

[12] Nabokov, Vladimir. Lectures on literature. Houghton Mifflin Harcourt, 2017.

[13] Pallarés-García, Elena. "Narrated perception revisited: The case of Jane Austen's Emma." Language and Literature 21.2 (2012): 170-188.

[14] Wright, Andrew. Jane Austen's Novels: A Study in Structure. Chatto and Windus, 1953. 